\title{
HUBUNGAN KAUSALITAS ANTARA NILAI TUKAR DAN INFLASI DI INDONESIA SELAMA PERIODE 2001 - 2010
}

\author{
Bobby Yuga Hutama \\ Birgitta Dian Saraswati \\ Universitas Kristen Satya Wacana \\ e-mail: birgitta.saraswati@staff.uksw.edu
}

\begin{abstract}
ABSTRAK
Indonesia is a small open economy, and has a monetary policy strategy of targeting inflation in consumer prices. In this paper, we look at the evidence from the Indonesia on inflation behaviour, and examine the propositions from several theoretical models about inflation dynamics in an open economy, focussing in particular on the hypothesised connections between the exchange rate and consumer price inflation. The objective of this research is to find out whether the relationship between inflation and exchange rate in Indonesia data during the period of 2001-2010. The method of analysis used in the study is Granger Causality Model to examine the interaction between inflation and the exchange rate in the Indonesia. The results show that the Granger causality between inflation and the exchange rate is bidirectional.
\end{abstract}

Key words : Inflation, exchange rate, Granger causality test, Indonesia

\section{PENDAHULUAN}

Pertumbuhan dan kestabilan ekonomi, adalah dua syarat penting bagi kemakmuran dan kesejahteraan suatu bangsa. Dengan pertumbuhan ekonomi, negara dapat melanjutkan pembangunan dan memberi pelayanan yang lebih baik bagi rakyatnya. Dengan kestabilan, pembangunan dan pertumbuhan ekonomi dapat berjalan dengan baik. Oleh karena itu, pertumbuhan dan kestabilan ekonomi merupakan dua hal yang perlu diupayakan sebaik mungkin. Wardono (2009), menyatakan bahwa salah satu sumber ketidakstabilan ekonomi, yang dapat mengganggu pertumbuhan ekonomi adalah terjadinya kenaikan harga secara umum dan terus menerus, atau lebih dikenal dengan sebutan Inflasi. Variabel ekonomi ini dapat menimbulkan ketidakstabilan produktivitas sektor riil, turunnya daya saing komoditi ekspor di pasar internasional, ketidakstabilan distribusi pendapatan masyarakat, dan masih banyak lagi variable ekonomi lain yang terpengaruh dengan adanya inflasi ini.

Inflasi sering diartikan sebagai kecenderungan naiknya harga secara umum dan terus menerus, dalam waktu dan tempat tertentu (Mishkin, 2006:10), serta keberadaannya sering diartikan sebagai salah satu masalah utama dalam perekonomian negara, selain pengangguran dan ketidakseimbangan neraca pembayaran.

Indonesia sendiri pernah menghadapi tingkat inflasi yang lebih serius atau sangat tinggi, yaitu pada saat terjadi krisis moneter pada tahun 1998 dengan angka inflasi mencapai 77,60\%, kurs Rupiah terhadap Dolar Amerika menembus angka Rp. 16.000 per 1 dolar AS, dan PDB -13,20 \% (Kompas, 21 desember 1998). Krisis moneter tersebut diawali dengan terdepresiasinya secara 
tajam nilai tukar rupiah terhadap mata uang asing (terutama dolar Amerika), akibat adanya domino effect dari terdepresiasinya mata uang Thailand (bath).

Mahadeva (2000), menyatakan bahwa meskipun inflasi menjadi salah satu masalah besar dalam perekonomian, namun dampak positif inflasi akan maksimal dengan tingkat inflasi yang agak rendah, berkisar antara 3.8\% - 7.4\% per tahun. Dengan kata lain, tingkat inflasi yang kurang atau lebih dari angka tersebut, akan memiliki kecenderungan memberi dampak negatif bagi perekonomian.

Dengan mempertimbangkan dampak inflasi terhadap perekonomian maka semua negara akan merumuskan kebijakan dalam rangka mencapai stabilitas tingkat harga. Bank Indonesia melalui UU No. 23 Tahun 1999, yang kemudian direvisi dengan UU No. 3 Tahun 2004 mengesahkan bahwa Bank Indonesia sebagai perumus kebijakan moneter mempunyai tujuan mencapai dan memelihara kestabilan nilai rupiah, baik terhadap barang dan jasa yang tercermin dalam inflasi maupun terhadap mata uang negara lain yang tercermin dalam nilai tukar atau kurs. Untuk mencapai tujuan tersebut, sejak tahun 2005 Bank Indonesia menerapkan kerangka kebijakan moneter dengan inflasi sebagai sasaran utama kebijakan moneter (Inflation Targeting Framework) dengan menganut sistem nilai tukar yang mengambang (free floating).

Keberhasilan kebijakan Inflation Targeting Framework (ITF) sendiri tergantung dari hubungan antara inflasi dengan variabel-variabel sasaran akhir makro ekonomi lainya, salah satunya adalah tergantung dari hubungan antara inflasi dengan nilai tukar.

Studi tentang hubungan antara inflasi dan nilai tukar telah dilakukan selama beberapa dekade. Hasil penelitian Jean-Claude maswana (2006) menemukan bahwa di Kongo terjadi hubungan dua arah antara inflasi dengan nilai tukar dalam jangka pendek dan terjadi hubungan satu arah antara inflasi dengan nilai tukar dalam jangka panjang, di mana nilai tukar mempengaruhi inflasi dalam jangka panjang. Noer Azam Achsani (2010) dalam melihat hubungan antara inflasi dengan nilai tukar dibedakan antara anggotaanggota negara ASEAN, Uni Eropa dan North America, hasil dari penelitian tersebut adalah terdapat korelasi yang kuat antara inflasi dan nilai tukar disemua kelompok negara. Untuk Asia, terdapat hubungan satu arah antara inflasi dengan nilai tukar di mana nilai tukar mempengaruhi inflasi. Sebaliknya di negara-negara Non Asia terjadi hubungan yang sebaliknya di mana inflasi yang mempengaruhi nilai tukar. Temuan menarik dari penelitian tersebut adalah sensitifitas inflasi terhadap perubahan nilai tukar lebih kuat terjadi di negara ASEAN dibanding dengan Uni Eropa dan North America. Perbedaan perilaku hubungan inflasi dengan nilai tukar di beberapa negara tersebut yang mendorong peneliti untuk mengetahui hubungan antara inflasi dengan nilai tukar di Indonesia.

Untuk itu diperlukan studi yang mengkaji hubungan antara tingkat inflasi dan nilai tukar di Indonesia. Berdasarkan masalah penelitian tersebut, maka persoalan penelitian yang diajukan oleh peneliti adalah bagaimana hubungan antara inflasi dengan nilai tukar yang terjadi di Indonesia.

\section{REVIEW LITERATUR DAN HIPOTESIS}

\section{Nilai Tukar}

Nilai tukar menurut Mishkin (2006) didefinisikan sebagai harga/nilai suatu mata uang terhadap mata uang lain. Sementara Krugman (2000) menjelaskan nilai tukar sebagai harga sebuah mata uang yang diukur atau dinyatakan 
dalam mata uang lain. Nilai tukar mata uang suatu negara dapat dibedakan menjadi dua, yaitu nilai tukar nominal dan nilai tukar riil. Nilai tukar nominal merupakan harga relatif mata uang dua negara (Mankiw, 2003:127). Nilai tukar riil di antara kedua negara dihitung dari nilai tukar nominal dan tingkat harga di kedua negara.

\section{Inflasi}

Mishkin (2006) menyatakan bahwa Inflasi diartikan sebagai kenaikan tingkat harga secara umum dan terus menerus. Kenaikan harga dari satu atau dua barang saja tidak dapat disebut inflasi kecuali bila kenaikan itu meluas (atau mengakibatkan kenaikan harga) pada barang lainnya. Menurut Rahardja dan Manurung (2004), suatu perekonomian bisa dikatakan telah mengalami inflasi jika tiga karakteristik berikut dipenuhi, yaitu: 1) terjadi kenaikan harga, 2) kenaikan harga bersifat umum, dan 3) berlangsung terus-menerus.

\section{Teori inflasi monetaris}

Menurut teori ini inflasi terjadi sebagai akibat adanya pertumbuhan uang yang beredar yang jauh melebihi pertumbuhan permintaan akan uang. Jika jumlah uang yang beredar bertambah melebihi permintaan akan uang, maka pembelanjaan untuk barang dan jasa akan bertambah sehingga akan mengakibatkan pertambahan produksi atau kenaikan harga. Dengan asumsi bahwa tingkat output nasional berada pada tingkat produksi dengan kapasitas penuh (full-employment level), maka kita peroleh hubungan yang langsung antara perubahan jumlah uang yang beredar dengan perubahan tingkat harga umum (Arief, 1996 : 235). Hubungan jumlah uang beredar dengan tingkat inflasi dapat dijelaskan dengan gambar berikut ini:

\section{Gambar 1}

Pengaruh pertambahan jumlah uang beredar secara terus menerus terhadap tingkat harga

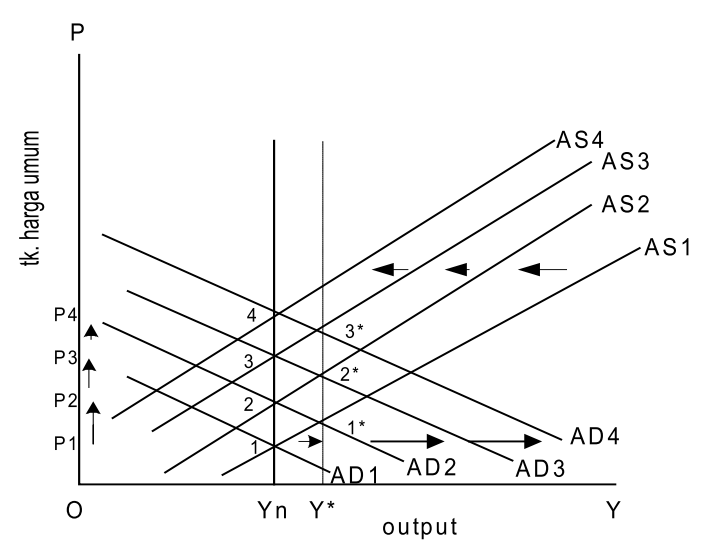

Keterangan :

$\mathrm{P}$ adalah tingkat harga umum

$\mathrm{AD}$ adalah kurva permintaan agregat (agregat demand)

AS adalah kurva penawaran agregat (agregat supply)

$\mathrm{Y}_{\mathrm{n}}$ adalah tingkat output alamiah

Pada kondisi awal, perekonomian berada pada titik 1 dimana pada titik 1 tersebut tingkat output dan tingkat harga berada pada posisi $\mathrm{P}_{1}$ ( yaitu perpotongan antara kurva permintaan agregat $\mathrm{AD}_{1}$ dengan kurva penawaran agregat $\mathrm{AS}_{1}$ ). Apabila kemudian jumlah uang beredar meningkat, maka kurva permintaan agregat akan bergeser ke kanan atas yaitu dari $\mathrm{AD}_{1}$ menjadi $\mathrm{AD}_{2}$. Dalam jangka pendek, maka perekonomian akan berge-rak ke titik $1^{*}$ dan tingkat output akan meningkat melebihi tingkat alamiahnya yaitu dari $\mathrm{Y}_{\mathrm{n}}$ menjadi $\mathrm{Y}^{*}$. Pada kondisi ini maka tingkat pengangguran akan turun menjadi di bawah tingkat pengangguran alamiah dan akibat selanjutnya tingkat upah akan meningkat. Peningkatan tingkat upah tersebut akan mendorong kurva penawaran agregat bergeser ke kiri atas menjadi $\mathrm{AS}_{2}$, sehingga perekonomian akan 
kembali ke tingkat alamiahnya yaitu pada titik 2 . Pada kondisi keseimba-ngan yang baru tersebut tingkat harga naik dari $\mathrm{P}_{1}$ menjadi $\mathrm{P}_{2}$.

Apabila jumlah uang beredar meningkat pada tahun berikutnya, maka kurva permintaan agregat akan bergeser ke kanan atas lagi menjadi $\mathrm{AD}_{3}$ dan kurva penawaran agregat juga akan bergeser dari $\mathrm{AS}_{2}$ menjadi $\mathrm{AS}_{3}$, sehingga perekonomian akan bergerak dari titik $2 *$ menjadi 3 dimana dalam kondisi tersebut tingkat harga naik dari $\mathrm{P}_{2}$ menjadi $P_{3}$. Jika jumlah uang beredar terus meningkat pada tahun-tahun berikutnya maka perekonomian akan terus-menerus mengalami peningkatan harga. Atau dengan kata lain bahwa : jika jumlah uang beredar tumbuh secara terus menerus maka hal ini akan mendorong terjadinya inflasi.

Menurut kaum Monetaris, tidak ada faktor lain selain pertumbuhan jumlah uang beredar yang dapat menyebabkan terjadinya peningkatan tingkat harga secara terus menerus. Selain itu jumlah uang beredar dipandang sebagai satu-satunya faktor yang menyebabkan pergeseran kurva permintaan agregat

\section{Teori Keynesian (Mishkin, 2006 : 642-650)}

Menurut analisa Keynesian, pertumbuhan jumlah uang beredar yang terjadi secara terus menerus akan berpengaruh terhadap kurva penawaran agregat dan kurva permintaan agregat. Analisa Keynesian sama dengan analisa Monetaris yaitu bahwa pertumbuhan jumlah uang beredar yang cepat akan menyebabkan tingkat harga naik secara terus menerus sehingga mengakibatkan terjadinya inflasi. Berbeda dengan pandangan monetaris yang menyatakan bahwa jumlah uang beredar merupakan satu-satunya penyebab penting dalam pergeseran kurva aggregat demand, menurut Keynesian ada faktor-faktor selain perubahan jumlah uang beredar yang berpengaruh terhadap kurva penawaran agregat dan permintaan agregat, seperti: kebijakan fiskal dan adanya goncangan (shock) dari sisi penawaran.

Keynesian juga memandang inflasi sebagai fenomena moneter, sehingga menurut Keynesian : inflasi tidak bisa hanya disebabkan oleh adanya kebijakan fiskal semata atau karena goncangan penawaran tanpa adanya perubahan jumlah uang beredar.

Hal ini dapat dijelaskan dengan gambar dibawah ini. inflasi

- Dampak kebijakan fiskal terhadap tingkat

$$
\begin{gathered}
\text { Gambar } 2 \\
\text { Pengaruh kenaikan pengeluaran } \\
\text { pemerintah secara sesaat terhadap tingkat } \\
\text { harga }
\end{gathered}
$$

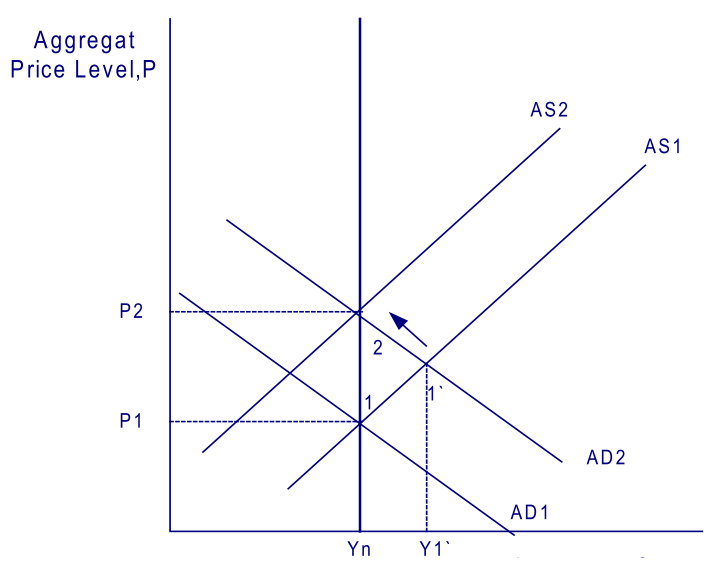

Keterangan :

$\mathrm{AD}$ adalah kurva permintaan agregat (agregat demand).

AS adalah kurva penawaran agregat (agregat supply).

$\mathrm{P}$ adalah tingkat harga umum.

Yn adalah tingkat output alamiah.

Pada awalnya perekonomian berada pada titik 1 dimana tingkat output yang terjadi merupakan tingkat output alamiah dan tingkat harga yang terjadi adalah $\mathrm{P}_{1}$. Apabila kemudian pemerintah melakukan kebijakan fiskal dengan meningkatkan 
pengeluaran pemerintah, maka kurva permintaan agregat akan bergeser ke kanan atas dari $\mathrm{AD}_{1} \mathrm{ke}$ $\mathrm{AD}_{2}$ dan keseimbangan perekonomian bergerak ke titik 1'. Pada titik 1', tingkat output yang terjadi melebihi tingkat output alamiah $\left(\mathrm{Y}_{1},>\mathrm{Y}_{1}\right)$. Kondisi ini mendorong kurva penawaran agregat bergeser ke kiri atas menjadi $\mathrm{AS}_{2}$, sehingga keseimbangan perekonomian akan bergerak ke titik 2. Pada titik keseimbangan yang baru ini, tingkat output kembali ke tingkat alamiah dan tingkat harga naik dari $\mathrm{P}_{1}$ menjadi $\mathrm{P}_{2}$.

Pada saat perekonomian bergerak dari titik 1 menuju 1' kemudian menuju pada titik 2 maka tingkat harga akan naik dan perekonomian mengalami inflasi. Tetapi setelah kemudian akhirnya perekonomian berada pada titik 2 maka tingkat inflasi adalah nol. Disini dapat diketahui bahwa satu kali tindakan meningkatkan pengeluaran pemerintah hanya akan menyebabkan tingkat inflasi sesaat dan bukan inflasi yang merupakan kenaikan tingkat harga secara terus menerus.

Tetapi jika pengeluaran pemerintah dinaikkan terus menerus maka perekonomian akan mengalami kenaikan harga yang terus menerus pula. Dalam hal ini maka analisa Keynesian akan menolak dalil Friedman yang menyatakan bahwa inflasi selalu merupakan hasil dari pertumbuhan jumlah uang beredar. Tetapi meningkatkan pengeluaran pemerintah secara terus menerus merupakan kebijakan yang tidak mungkin dilakukan. Hal ini karena ada batasan terhadap jumlah total pengeluaran pemerintah. Pemerintah tidak dapat membelanjakan $100 \%$ atau labih dari GDP. Salah satu kesimpulan dari analisa Keynesian adalah bahwa tingkat inflasi yang tinggi tidak dapat hanya diatasi dengan kebijakan fiskal saja.

Dampak fenomena penawaran terhadap tingkat inflasi

Adanya goncangan penawaran seperti adanya tuntutan dari para pekerja atas peningkatan upah akan menyebabkan kurva penawaran agregat bergeser ke kiri atas. Hal ini menyebabkan orang akan berpikir bahwa fenomena penawaran semata akan mendorong terjadinya inflasi. Pemikiran seperti tersebut menurut Keynesian adalah tidak benar. Gambar di bawah ini akan menjelaskan pemikiran Keynesian tersebut.

\section{Gambar 3}

Pengaruh goncangan penawaran terhadap tingkat harga

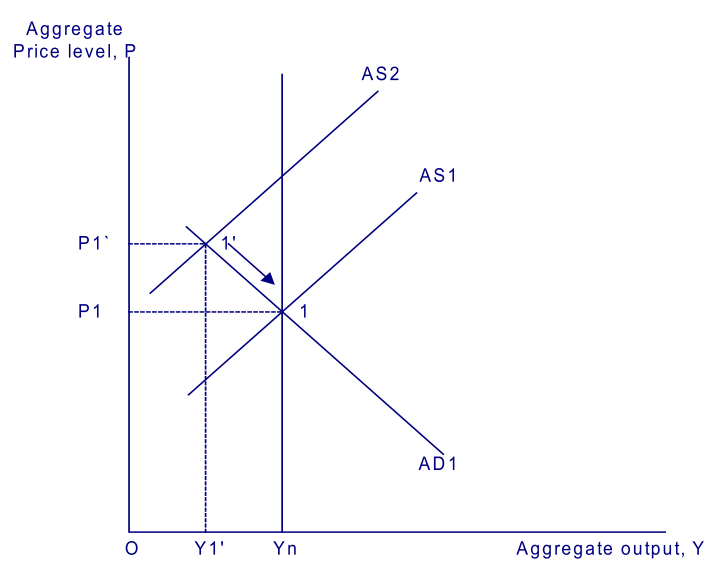

Keterangan :

AD adalah kurva permintaan agregat (agregat demand).

AS adalah kurva penawaran agregat (agregat supply).

$\mathrm{P}$ adalah tingkat harga umum.

Yn adalah tingkat output alamiah.

Gambar 3 di atas menjelaskan bahwa jika dalam suatu perekonomian terjadi goncangan penawaran yang sifatnya negatif, seperti: adanya embargo minyak, maka hal ini akan menyebabkan harga minyak meningkat sehingga akibat selanjutnya para buruh akan menuntut kenaikan upah. Kondisi ini mengakibatkan kurva penawaran agrgat bergeser ke kiri atas dari $\mathrm{AS}_{1}$ ke $\mathrm{AS}_{2}$. Sementara kurva permintaan agregat tidak mengalami pergeseran karena jumlah uang beredar dalam perekonomian tidak 
mengalami perubahan. Dengan pergeseran kurva penawaran agregat maka kondisi keseimbangan perekonomian bergerak menuji titik 1'. Pada titik 1 ' tersebut tingkat harga naik dari $\mathrm{P}_{1}$ menjadi $\mathrm{P}_{1}$, dan tingkat output akan turun dari $\mathrm{Y}_{\mathrm{n}}$ menjadi $\mathrm{Y}_{1}$ '. Tingkat output $\mathrm{Y}_{1}{ }^{\prime}$ berada di bawah tingkat output alamiah $\left(\mathrm{Y}_{1}<\mathrm{Y}_{1}{ }^{\prime}\right)$ yang berarti tingkat pengangguran yang terjadi lebih besar dari tingkat pengangguran alamiah. Hal ini menyebabkan kurva penawaran agregat bergeser ke kanan bawah kembali pada kurva $\mathrm{AS}_{1}$ dan kondisi keseimbangan perekonomian kembali ke titik 1. Dengan kata lain bahwa ada-nya goncangan penawaran hanya akan berdampak pada kenaikan harga secara sesaat dan tidak berdampak pada tingkat inflasi

\section{Hubungan antara inflasi dengan nilai tukar}

Salah satu teori yang menjelaskan hubungan antara tingkat harga atau inflasi dengan pergerakan nilai tukar adalah teori paritas daya beli (Purchasing Power Parity Theory). Teori ini didasarkan pada hukum The law of one price (LOP) yang mengatakan jika dua negara memproduksi satu jenis barang yang identik, dengan biaya transportasi dan hambatan perdagangan yang sangat kecil maka harga dari barang tersebut seharusnya sama diseluruh dunia tidak peduli negara mana yang memproduksinya (Mishkin, 2006:507).

Purchasing Power Parity menjelaskan bahwa nilai tukar diantara dua negara akan menyesuaikan perubahan tingkat harga diantara dua negara (Mishkin, 2006:507). Dengan kata lain bahwa apabila suatu negara mengalami inflasi maka nilai tukar dinegara tersebut akan melakukan penye-suaian terhadap terjadinya inflasi tersebut yaitu nilai tukar tersebut akan mengalami penurunan nilai (depresiasi). Hal ini bisa terjadi karena ketika suatu negara mengalami inflasi maka harga produk yang dihasilkan oleh negara tersebut menjadi tidak kompetitif di pasar dunia sehingga mengalami ekspor mengalami penurunan. Dengan adanya penurunan ekspor sedangkan kondisi permintaa barang impor tetap akan menyebabkan permintaan mata uang asing di pasar valas meningkat sehingga mata uang domestik akan mengalami depresiasi.

Sebaliknya pengaruh nilai tukar terhadap inflasi bisa dijelaskan dari teori inflasi menurut keynes. Keynes berpendapat bahwa inflasi tidak hanya di sebabkan oleh pertumbuhan jumlah uang beredar saja tetapi karena adanya goncangan-goncangan dari penawaran. Dengan kata lain selain inflasi dari sisi permintaan (demand pull inflation), keynes juga menjelakskan terjadinya cost push inflation.

Inflasi dari sisi permintaan (demand pull inflation), disebabkan oleh peningkatan permintaan di mana persediaan produksi dalam negri tidak dapat memenuhi atau terjadi out put gap kebutuhan sehingga pemerintah melakukan kebijakan impor barang. Ketika terjadi kenaikan harga barang di pasar dunia, maka hal tersebut tidak hanya mengakibatkan harga barang impor yang dijual di dalam negri menjadi lebih mahal (inflasi), tapi juga mengakibatkan harga-harga barang-barang yang menggunakan bahan baku impor menjadi naik. Dengan demikian apabila terjadi pergerakan nilai tukar akan mendorong terjadinya inflasi, maka apabila suatu negara mengalami depresiasi mata uangnya maka harga barang impor menjadi lebih mahal dan mengalami kenaikan harga jual di dalam negri. Untuk konteks negara-negara berkembang di mana penggunaan bahan baku input mengandung komponen impor yang tinggi, depresiasi mata uang mengakibatkan harga impor lebih tinggi, yang kemudian mempengaruhi biaya dan harga produk akhirnya dalam perekonomian dan akan menyebabkan tekanan inflasi di dalam negeri yang cukup besar (Maswana 2006). 
Gambar dibawah ini menggambarkan skema pengaruh nilai tukar terhadap inflasi

\section{Gambar 4}

Skema pengaruh nilai tukar terhadap inflasi

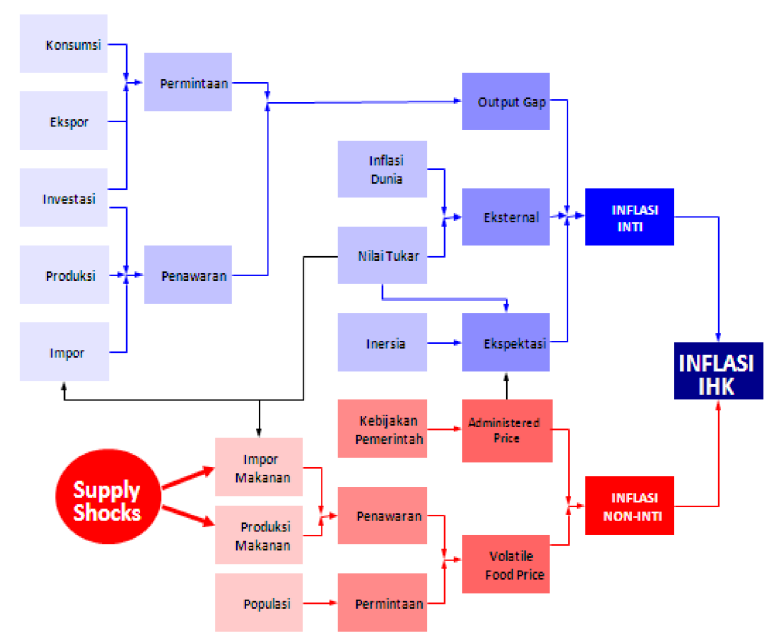

Sumber: Bank Indonesia

\section{Tinjaun Pustaka}

Maswana (2006) menguji hubungan kausalitas antara inflasi dan nilai tukar di Kongo dengan menggunakan uji Hsiao's Granger NonCausality. Menghasilkan temuan bahwa terdapat hubungan kausalitas antara inflasi dan nilai tukar secara dua arah dalam jangka pendek, namun dalam jangka panjang nilai tukar hanya menyebabkan inflasi tanpa efek umpan balik. Achsani, Fauzi dan Abdullah (2010) melakukan analisis perbandingan hubungan antara nilai tukar riil dan inflasi antara ASEAN+3, Uni Eropa, dan Amerika Utara pada periode tahun 1991 hingga 2005 dengan menggunakan uji kausalitas Granger. Hasil penelitian menunjukan bahwa perilaku inflasi di wilayah Asia tampaknya berbeda dengan perilaku inflasi dari Uni Eropa dan Amerika Utara. Di wilayah Asia, Nilai tukar memiliki pengaruh signifikan terhadap inflasi artinya depresiasi nilai tukar memiliki dampak signifikan terhadap pergerakan inflasi, tapi tidak dalam arah yang berlawanan. Sebaliknya, di wilayah non Asia, inflasi memiliki dampak yang signifikan terhadap nilai tukar, tapi tidak dalam arah yang berlawanan. Inflasi di negara-negara non-Asia secara signifikan dipengaruhi oleh inflasi domestik dan asing.

\section{Rumusan Hipotesis}

Berdasarkan landasan teori dan tinjauan pustaka di atas maka hipotesis dalam penelitian ini adalah sebagai berikut:

Hipotesis I : nilai tukar mempengaruhi tingkat inflasi di Indonesia

$\mathrm{Ho}_{1}$ : Nilai tukar tidak mempengarhi Inflasi (Ho $\left.: \beta_{j} \beta_{j}=0\right)$

$\mathrm{Ha}_{1}$ : Nilai Tukar mempengaruhi Inflasi (Ho : $\beta_{j} \beta_{j} \neq 0$ )

Hipotesis II : tingkat inflasi mempengaruhi nilai tukar di Indonesia

$\mathrm{Ho}_{2}$ : Inflasi tidak mempengaruhi nilai tukar $\left(\right.$ Ho $: \delta_{j} \delta_{j}=0$ )

$\mathrm{Ha}_{2}$ : Inflasi mempengaruhi nilai tukar (Ho $: \delta_{j}$ $\left.\delta_{j} \neq 0\right)$

\section{METODE PENELITIAN}

Data yang digunakan dalam penelitian ini adalah data sekunder berupa indeks harga konsumen (IHK) sebagai proxy tingkat inflasi dan nilai tukar nominal. Semuanya adalah data time series tahunan yang bersifat nasional untuk periode waktu 2001-2010. Sumber data dalam penelitian ini berasal dari berbagai laporan yang terkait seperti publikasi yang dihitung setiap tahun oleh Badan Pusat Statistik (BPS) untuk variabel IHK dan Laporan Tahunan Bank Indonesia(BI) untuk variabel nilai tukar.

Teknik analisis yang digunakan dalam penelitian ini adalah teknik analisis kuantitatif dengan menggunakan metode Granger causality test untuk menguji hubungan kausalitas antara variabel tingkat inflasi dengan nilai tukar. Uji kausalitas Granger pada penelitian ini diformulasikan dengan persamaan sebagai berikut: 
$I N F_{\mathrm{t}}=\sum_{i=1}^{n} \alpha_{\mathrm{i}} \epsilon_{\mathrm{t}-\mathrm{i}}+\sum_{j=1}^{n} \beta_{j} I N F_{\mathrm{t}-j}+u_{1 \mathrm{t}}$

$\epsilon_{t}=\sum_{i=1}^{n} \lambda_{i} I N F_{t-i}+\sum_{j=1}^{n} \delta_{j} \epsilon_{t-j}+u_{2 t}$

Dimana $I N F I N F=$ tingkat inflasi, $\epsilon €=$ nilai tukar, $t-j t-j=$ panjang lag, $u_{1 t} u_{1 t}$ dan $u_{2 t} u_{2 t}$ adalah white noise errors yang tidak berkorelasi satu sama lain, Uji ini dilakukan untuk melihat apakah nilai tukar memperngaruhi inflasi atau sebaliknya tingkat inflasi yang mempengaruhi nilai tukar.

Dalam uji kausalitas Granger salah satu hal penting yang terlebih dahulu harus dilakukan ialah mencari panjang lag yang memberikan hasil estimasi terbaik, dalam hal ini berarti harus di uji dari beberapa model lag alternatif mana model lag yang terbaik. Pada penelitian ini jumlah lag yang akan digunakan di dasarkan pada uji Akaike Information Criterion (AIC), dimana kriteria pengujian panjang lag optimal yang digunakan diperoleh dengan mencari nilai AIC yang paling kecil.

Dalam menerapkan uji kausalitas Granger, ada beberapa langkah yang harus dilakukan $(\mathrm{Gu}-$ jarati 2009:654): pertama, meregresikan variabel dependen secara terpisah dalam semua lag dengan metode restricted regression, dalam penelitian ini variabel dependen adalah IHK untuk persamaan (1) dan variabel kurs sebagai variabel dependen dalam persamaan (2). dari hasil regresi diatas maka akan diperoleh nilai AIC paling kecil untuk masing masing variabel. Kedua, melakukan unrestricted regreesion, yaitu meregresikan dependen variabel dengan nilai AIC terkecil dengan variabel lainya. Ketiga, melakukan hipotesis untuk persamaan model (1) dan (2). Keempat, untuk menentukan maka hipotesis diatas terpenuhi atau tidak, maka pengujian Granger menggunakan uji $\mathrm{F}$ dengan formulasi sebagai berikut

$$
\begin{aligned}
& F=\frac{\left(R S S_{R}-R S S_{U R}\right) / m}{R S S_{U R} /(n-k)} \\
& F=\frac{\left(R S S_{R}-R S S_{U R}\right) / m}{R S S_{U R} /(n-k)}
\end{aligned}
$$

Dimana $\mathrm{RSS}_{\mathrm{R}}=$ residual sum of square, indeks $\mathrm{R}$ menyatakan restricted regression dan UR menyatakan unrestrected regression, sedangkan $\mathrm{m}$ menyatakan tenggang waktu senjang, $\mathrm{n}$ menyatakan jumlah observasi dan $\mathrm{k}$ adalah jumlah parameter yang di estimasi pada unrestrected. Jika hasil perhitungan dari rumus di atas didapat bahwa nilai $\mathrm{F}$ hitung melebihi nilai $\mathrm{F}$ tabel, maka hipotesis (Ho) ditolak dan (Ha) diterima.

\section{HASIL PENELITIAN DAN PEMBAHASAN}

Dari hasil perhitungan nilai AIC menggunakan lag 1 sampai dengan lag 12 diperoleh nilai AIC untuk persamaan restricted dan unrestricted sebagai berikut:

Tabel 1

Uji panjang lag dengan IHK sebagai dependen variabel

\begin{tabular}{|l|c|c|}
\hline Lag & $\begin{array}{c}\text { Nilai AIC } \\
\text { (restricted } \\
\text { regression) }\end{array}$ & $\begin{array}{c}\text { Nilai AIC } \\
\text { (unrestricted regression) } \\
\text { variabel Kurs }\end{array}$ \\
\hline IHK(t-1) & 16,31 & 16,29 \\
\hline IHK(t-2) & 16,36 & 16,35 \\
\hline IHK(t-3) & 16,44 & 16,41 \\
\hline IHK(t-4) & 16,51 & 16,49 \\
\hline IHK(t-5) & 16,59 & 16,56 \\
\hline IHK(t-6) & 16,68 & 16,62 \\
\hline IHK(t-7) & 16,77 & 16,63 \\
\hline IHK(t-8) & 16,85 & 16,63 \\
\hline IHK(t-9) & 16,93 & 16,74 \\
\hline IHK(t-10) & 17,01 & 16,52 \\
\hline IHK(t-11) & 17,09 & 16,02 \\
\hline IHK(t-12) & 17,11 & 16,004 \\
\hline
\end{tabular}

Dari tabel di atas menunjukan hasil dari uji panjang lag untuk persamaan model (1) dimana 
IHK sebagai variabel dependen. Terlihat bahwa untuk model restricted regression, IHK pada Lag 1 mempunyai nilai AIC paling kecil yaitu sebesar 16,31. Sedangkan model unrestricted regrresion untuk variabel kurs berada pada lag 12 dengan nilai AIC 16,004. Sehingga persamaan (1) dapat dituliskan sebagai berikut:

$I N F_{\mathrm{t}}=\sum_{\mathrm{i}=1}^{12} \alpha_{\mathrm{i}} \epsilon_{\mathrm{t}-12}+\sum_{j=1}^{1} \beta_{j} I N F_{\mathrm{t}-1}+u_{1 \mathrm{t}}$

\section{Tabel 2}

Uji panjang Lag dengan Kurs sebagai variabel dependen

\begin{tabular}{|l|c|c|}
\hline \multicolumn{1}{|c|}{ Lag } & $\begin{array}{c}\text { Nilai AIC } \\
\text { (restricted } \\
\text { regression) }\end{array}$ & $\begin{array}{c}\text { Nilai AIC } \\
\text { (unrestricted regression) } \\
\text { variabel IHK }\end{array}$ \\
\hline KURS(t-1) & 15,67 & 15,36 \\
\hline KURS(t-2) & 15,63 & 15,08 \\
\hline KURS(t-3) & 15,48 & 15,11 \\
\hline KURS(t-4) & 15,47 & 15,16 \\
\hline KURS(t-5) & 15,32 & 15,2 \\
\hline KURS(t-6) & 15,37 & 15,28 \\
\hline KURS(t-7) & 15,4 & 15,3 \\
\hline KURS(t-8) & 15,48 & 15,38 \\
\hline KURS(t-9) & 15,32 & 15,46 \\
\hline KURS(t-10) & 15,42 & 15,28 \\
\hline KURS(t-11) & 15,45 & 15,4 \\
\hline KURS(t-12) & 15,47 & 15,46 \\
\hline
\end{tabular}

(sumber : lampiran 5)

untuk persamaan model (2) terlihat bahwa dalam restricted regression, kurs pada Lag 5 mempunyai nilai AIC paling kecil yaitu sebesar 15,32. Sedangkan model unrestricted regrresion untuk variabel IHK berada pada lag 2 dengan nilai AIC 15,08. Sehingga persamaan (2) dapat ditulis sebagai berikut:

$\epsilon_{t}=\sum_{i=1}^{2} \lambda_{i} I N F_{t-2}+\sum_{j=1}^{5} \delta_{j} \epsilon_{t-5}+u_{2 t}$

\section{Estimasi data}

Setelah melalui tahapan pencarian panjang lag, maka diperoleh 2 model sebagai berikut:

$I N F_{\mathrm{t}}=\sum_{\mathrm{i}=1}^{12} \alpha_{\mathrm{i}} €_{\mathrm{t}-12}+\sum_{j=1}^{1} \beta_{j} I N F_{\mathrm{t}-1}+u_{1 \mathrm{t}}$

$\epsilon_{\mathrm{t}}=\sum_{i=1}^{2} \lambda_{\mathrm{i}} I N F_{\mathrm{t}-2}+\sum_{j=1}^{5} \delta_{j} \epsilon_{\mathrm{t}-5}+u_{2 \mathrm{t}}$

Kedua model di atas, model persamaan (3) dan (4) adalah model yang akan di estimasi dalam penelitian, kedua model tersebut juga sudah melalui tahap uji asumsi klasik dan dinyatakan lolos autokorelasi dan heterokedastisitas. Adapun hasil estimasi persamaan 3 ditunjukan pada tabel di bawah ini

Tabel 1. Hasil estimasi pengaruh nilar tukar terhadap inflasi

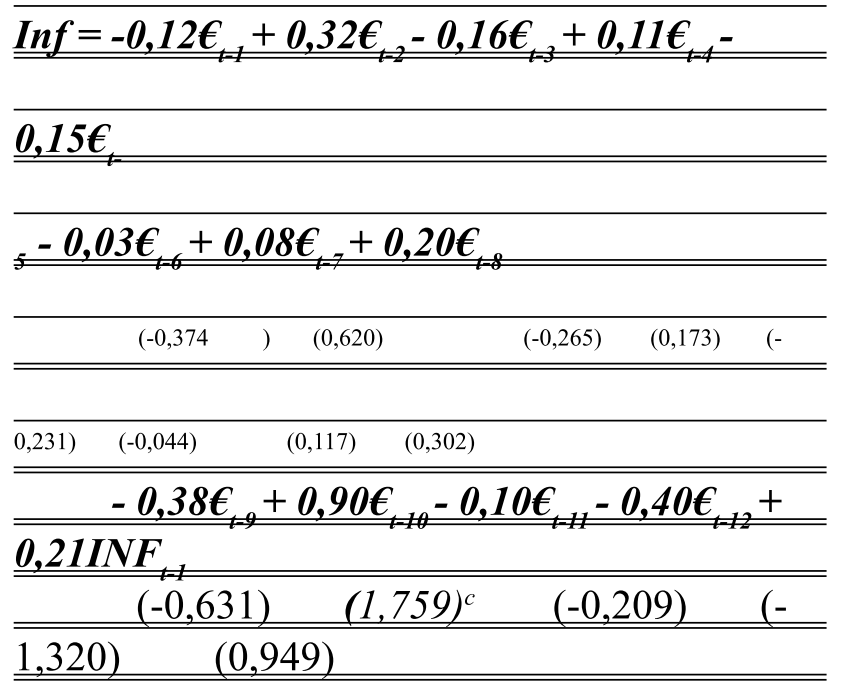

R-squared $=0.309145$

Adjusted R-squared $=-0.243539$

Durbin-Watson stat $=1.729483$

Keterangan: c. signifikan pada $\alpha=10 \%$

Hasil estimasi menunjukan bahwa untuk persamaan model (3) didapat nilai $R S S_{R} R S S_{R}$ 
$=26387491$ dan nilai $R S S_{U R} R S S_{U R}=5781579$ (Sumber: lampiran 2) sehingga dengan menggunakan formula uji $\mathrm{F}$ diperoleh nilai $\mathrm{F}$ hitung sebesar 8,01. Nilai $F$ hitung tersebut lebih besar dari F tabel sebesar 2,10 sehingga Ho ditolak dan $\mathrm{Ha}$ diterima, ini menunjukan bahwa nilai tukar berpengaruh terhadap tingkat inflasi di Indonesia.

Selain itu, hasil estimasi di atas memperlihatkan bahwa variabel nilai tukar pada 10 kwartal yang lalu mempunyai pengaruh positif dan signifikan terhadap tingkat inflasi pada kwartal saat ini (periode t) yang berarti bahwa apabila mata uang Rupiah $(\mathrm{Rp})$ terdepresiasi atau melemah terhadap US \$ sebesar Rp. 1,- maka akan diikuti kenaikan inflasi domestik sebesar 0,90\%. Hasil ini sesuai dengan hasil penelitian Achsani Fauzi yang mengemukakan bahwa di Asia nilai tukar berpengaruh terhadap inflasi secara berlawanan yang berarti bahwa perubahan nilai tukar suatu negara akan mengakibatkan terjadinya inflasi. Hal ini disebabkan Indonesia merupakan negara sedang berkembang dengan derajad ketergantungan sektor riil terhadap bahan baku impor tinggi. Berbeda dengan hubungan antara inflasi dengan nilai tukar di atas, persamaan di bawah ini menjelaskan pengaruh antara nilai tukar dengan inflasi.

Tabel 3

Hasil estimasi pengaruh inflasi terhadap nilai tukar

\begin{tabular}{|c|c|c|}
\hline \multicolumn{3}{|c|}{$\begin{array}{l}=-0,28 \operatorname{Inf} f_{t-1}+0,283 \operatorname{Inf} f_{t-2}+1,190 \epsilon_{t-1}-0,551 \epsilon_{t-2} \\
+0,427 \epsilon_{t-3}-0,183 \epsilon_{t-4}+0,110 \epsilon_{t-5}\end{array}$} \\
\hline$(-3,164)^{a}$ & $(3,385)^{a}$ & $(8,350)^{a}$ \\
\hline 2,691$)^{b}$ & $(-1,120)$ & $(0,922)$ \\
\hline
\end{tabular}

\begin{tabular}{ll}
\hline R-squared & $=0.670658$ \\
\hline Adjusted R-squared & $=0.600085$ \\
\hline Durbin-Watson stat & $=1.851335$
\end{tabular}

Keterangan: a. signifikan pada $\alpha=1 \%$

b. signifikan pada $\alpha=5 \%$
Berdasarkan estimasi persamaan (4) diketahui nilai $R S S_{R} R S S_{R}=6949666$ dan nilai $R S S_{U R}$ $R S S_{U R}=4874591$ (lampiran 5) sehingga dapat diperoleh nilai F 7,02392 dan F tabel 2,46. Dengan membandingkan nilai $\mathrm{F}$ hitung dengan $\mathrm{F}$ tabel ,maka nilai $\mathrm{F}$ hitung $>\mathrm{F}$ tabel, hal ini berarti bahwa Ho ditolak dan Ha di terima yang berarti bahwa tingkat inflasi berpengaruh terhadap pergerakan nilai tukar di Indonesia.

Pada lag pertama kuartal kesatu, dalam jangka pendek ketika terjadi peningkatan tingkat inflasi sebesar $1 \%$ akan menyebabkan nilai tukar Rupiah menguat sebesar Rp. 0,281,- terhadap Dolar Amerika, ini dimungkinkan Bank Indonesia sebagai otoritas moneter melakukan kebijakan moneter uang ketat (tight money policy) untuk mengendalikan inflasi melalui perubahan jumlah uang beredar. Salah satu kebijkaan moneter yang di lakukan oleh BI tersebut adalah dengan cara menaikan tingkat suku bunga. Kenaikan suku bunga tersebut menyebabkan nilai suku bunga di dalam negri lebih tinggi dari pada suku bunga di luar negri sehingga dampak selanjutnya di harapkan dapat menarik minat para pemegang valuta asing untuk menginvestasikan modalnya ke Indonesia dan akan terjadi perpindahan aliran modal dari luar negri masuk ke Indonesia (capital inflow). Dengan adanya arus modal yang masuk ke Indonesia, maka permintaan Rupiah terhadap Dolar meningkat, yang mengakibatkan nilai mata uang Rupiah menguat (apresiasi). Di pasar barang, penguatan Rupiah tersebut mengakibatkan harga barang domestik lebih tinggi dari harga barang impor.

Sebaliknya pada kuartal kedua, ketika inflasi mengalami peningkatan sebesar $1 \%$, maka nilai tukar akan mengalami depresiasi sebesar Rp. 0,28,- terhadap Dolar Amerika. Ini sesuai dengan konsep tentang Purchasing Power Parity yang menjelaskan bahwa nilai tukar di dua negara akan menyesuaikan terhadap perubahan 
pada tingkat harga di kedua negara. Hubungan antara nilai tukar dengan inflasi di atas juga yang menyatakan bahwa ketika harga barang dalam negri mengalami kenaikan, maka berpengaruh pada komponen ekspor. Ekspor negara akan mengalami penurunan karena produk di dalam negri mengalami penurunan daya saing dengan produk luar negri dari segi harga. Dalam jangka panjang, Penurunan ekspor akan berpengaruh terhadap perubahan nilai tukar, karena dengan berkurang nya eskpor maka jumlah mata uang asing (Dolar Amerika) yang di tersedia di pasar valuta asing semakin berkurang, dengan asumsi jumlah permintaaan mata uang asing tetap, maka nilai tukar Rupiah terhadap Dolar Amerika akan mengalami kenaikan (depresiasi).

Dari hasil estimasi kedua persamaan di atas didapat bahwa hubungan inflasi dan nilai tukar di Indonesia adalah dua arah, artinya depresiasi nilai tukar akan menyebabkan perubahan tingkat inflasi dan sebaliknya, tingkat inflasi akan mengakibatkan perubahan nilai tukar. hasil ini sesuai dengan penelitian yang dilakukan oleh maswana (2006) dan Achsani, Fauzi dan Abdullah (2010) bahwa perilaku inflasi untuk kondisi negara berkembang sangat dipengaruhi oleh fluktuasi nilai tukar, sedangkan untuk wilayah asia, termasuk Indonesia, memiliki kerentanan tinggi untuk guncangan dalam nilai tukar dibandingkan dengan negara negara di Eropa dan Amerika Utara.

\section{KESIMPULAN DAN SARAN}

Penelitian antara pengaruh inflasi dan nilai tukar di Indonesia memberikan beberapa kesimpulan penting. Pertama, Ada hubungan kausalitas dua arah antara nominal perubahan nilai tukar dan inflasi di Indonesia. Kedua, berdasarkan uji panjang Lag yang optimal diperoleh bahwa pengaruh tingkat inflasi terhadap nilai tukar lebih cepat dibandingkan dengan pengaruh nilai tukar terha- dap tingkat inflasi dimana tingkat inflasi 2 kwartal sebelumnya akan mempengaruhi nilai tukar saat ini. Sedangkan nilai tukar 12 kwartal sebelumnya baru akan mempengaruhi tingkat inflasi saat ini. Hasil ini mengindikasikan bahwa begitu cepatnya pengaruh tingkat inflasi terhadap stabilitas nilai tukar rupiah. Dalam kaitanya dengan kebijakan moneter Bank Indonesia, kebijakan BI tersebut sudah tepat sekali menetapkan inflasi sebagai target Nominal Anchor nya atau dikenal dengan Inflation Targeting Framework (ITF), sehingga ketika tingkat inflasi dapat dikendalikan maka akan tercapai juga stablitias nilai tukar rupiah. Ketiga, mengingat begitu cepatnya pengaruhinflasi terhadap stabilitas nilai tukar, sedangkan inflasi tidak hanya disebabkan oleh perubahan jumlah uang beredar melainkan juga dapat disebabkan oleh goncangan-goncangan penawaran, maka yang dapat dilakukan oleh pemerintah dalam hal ini para pengambil kebijakan adalah selain mengendalikan jumlah uang beredar juga harus menjaga stabilitas sektor riil. Sebagai contoh dengan menjaga ketersediaan bahan pangan sebagai pendorong inflasi di sisi volatile food. Keempat, dengan mempertimbangkan begitu cepatnya pengaruh inflasi terhadap stabilitas nilai tukar, maka inflasi yang terkendali juga akan menyebabkan volatilitas nilai tukar tetap stabil. Hal ini akan berdampak pada kinerja ekspor Indonesia yang terus terjaga sehingga berpengaruh positif terhadap pertumbuhan ekonomi.

\section{DAFTAR PUSTAKA}

Achsani, A. Noer, Fauzi A. F. Jayanthy and Abdullah, Piter. 2010. European Journal of Economics, Finance and Administrative Sciences. "The Relationship between Inflation and Real Exchange Rate: Comparative Study between ASEAN+3, the EU and North America" 
Gujarati Damodar N and Porter, C. Dawn. 2003.

Basic Econometrics. Fourth Edition.

Singapure: McGrow-Hill

Krugman, Paul R. 2000. International economics

: theory and policy 5th ed. California:

Addison-Wesley

Manurung, H. Adler. And Manurung Jonni. 2009. Ekonomi Keuangan dan Kebijakan Moneter. Cetakan Pertama, Jakarta: Salemba Empat.

http://www.bi.go.id/web/id/Moneter/ Kalkulator+Kurs/

http://www.bi.go.id/web/id/Moneter/Inflasi/ Pengenalan+Inflasi/disagregasi.htm

http://www.bps.go.id/tab_sub/view. php? tabe l=1\&daftar $=1 \&$ id subyek $=03 \&$ notab $=6$

http://www.seasite.niu.edu/Indonesian/ Reformasi/Krisis_ekonomi.htm

Maswana, Jean-Claude. 2006. Granger NonCausality Test of the Inflation-Exchange Rate in the Democratic Congo, Revue Congolaise D'economie Congo Economic Revue, Document de Travail/Working Paper WP03/06-December.

Mankiw, G.N. 2007. Macroeconomics, fifth Edition. Worth Publisher

Mishkin, S. Frederic. 2006. The Economic of Money, Banking, and Financial Markets, Pearson Internasional Edition

Pohan, Aulia. 2008. Kerangka Kebijakan Moneter dan Implementasinya di Indonesia. Jakarta: RajaGrafindo Persada

Wardhjono, Ghazali. 2009. Analisis Pengaruh Laju Inflasi Tahun 2006-2007 Di Indonesia 